\title{
Sport and Nutrition Journal
}

Vol 1 No 1 - Juni 2019 (33-39)

https://journal.unnes.ac.id/sju/index.php/spnj/

\section{SUSU KACANG TANAH EFEKTIF MENURUNKAN BERAT BADAN DAN KADAR GLUKOSA DARAH REMAJA PUTRI OVERWEIGHT}

\author{
Syifa Aeni ${ }^{1}$, Desty Ervira Puspaningtyas ${ }^{1}$, Natalia Desy Putriningtyas ${ }^{2 *}$ \\ ${ }^{1}$ Program Studi S-1 Gizi Fakultas IImu Kesehatan Universitas Respati Yogyakarta \\ ${ }^{2 *}$ Program Studi S-1 Gizi Fakultas IImu Keolahragan Universitas Negeri Semarang \\ natalia.desy12@gmail.com
}

\begin{abstract}
ABSTRAK
Prevalensi obesitas di Daerah Istimewa Yogyakarta (DIY) pada kelompok umur 13 - 15 tahun sebesar $2,6 \%$ dan DIY masuk dalam 15 provinsi dengan prevalensi obesitas yang tinggi. Kasus overweight bahkan obesitas pada remaja dikarenakan konsumsi makanan rendah serat, tinggi energi, natrium dan gula serta kurang aktivitas fisik. Kacang tanah merupakan salah satu contoh makanan yang mengandung tinggi serat dengan energi rendah. Penelitian ini bertujuan enganalisis pengaruh pemberian susu kacang tanah terhadap berat badan dan kadar glukosa darah. Jenis penelitian adalah quasy experiment dengan one group pre post test design. Penelitian dilaksanakan di SMAN 6 dan SMAN 9 Yogyakarta dengan melibatkan 16 subyek. Pengambilan subyek menggunakan purposive sampling dengan kriteria inklusi berjenis kelamin perempuan, usia 15-18 tahun dengan IMT/U >+1 SD dan bersedia mengikuti penelitian. Data dianalisis menggunakan paired $t$ test. Berat badan dan kadar glukosa darah sebelum dan sesudah intervensi menunjukkan adanya penurunan masing- masing sebesar $0,69 \mathrm{~kg}$ dan $0,94 \mathrm{mg} / \mathrm{dl}$. Ada perbedaan berat badan sebelum dan sesudah intervensi susu kacang tanah selama empat belas hari $(p=0,016)$ tetapi untuk kadar glukosa darah menunjukkan bahwa tidak terdapat perbedaan kadar glukosa darah sebelum dan sesudah intervensi susu kacang tanah $(p=0,654)$. Ada perbedaan signifikan berat badan sebelum dan sesudah intervensi.
\end{abstract}

Kata Kunci : kacang tanah; berat badan; kadar glukosa darah; overweight

\begin{abstract}
The prevalence of obesity in the Special Region of Yogyakarta (DIY) in the age group 13-15 years is $2.6 \%$. DIY is included in 15 provinces with a high prevalence of obesity. The risk of overweight and obesity in adolescents occurs due to several factors such as excessive food, poor fibre intake, high in energy, sodium and sugar also lack physical activity. The aim of thiss study was analyzing the effect of giving peanut milk on body weight and blood glucose level in overweight female adolescents. This was an quasy experiment with one group pre-post test design. This research was conducted at SMAN 6 and SMAN 9 Yogyakarta. Subjects were 16 adolescents. Subjects were selected by purposive sampling method with criteria inclusion of female, aged 15-18 years with BMI/U >+1 SD and willing to take part in the study. Data were analyzed using paired $t$ - test. Body weight and blood glucose level before and after intervention showed a decrease of 0.69 and $0.94 \mathrm{mg} / \mathrm{dl}$, respectively. There was difference in body weight before and after the intervention of peanut milk for fourteen days $(p=0.016)$ but for blood glucose level showed that there was no difference $(p=0.654)$. There were significant the differences in body weight before and after the intervention.
\end{abstract}

Key words : peanut; body weight; blood glucose level; overweight

(C) 2019 Universitas Negeri Semarang 


\section{PENDAHULUAN}

Overweight merupakan kelebihan berat badan dibandingkan dengan berat badan ideal dikarenakan adanya penimbunan jaringan lemak (Purnamawati, 2009). Overweight merupakan masalah kesehatan dunia dengan jumlah prevalensi yang selalu meningkat setiap tahun, baik di negara maju maupun berkembang. Prevalensi overweight orang dewasa pada tahun 2014 sebanyak 1,9 milyar dengan persentase $39 \%$ mengalami kelebihan berat badan dan $13 \%$ mengalami obesitas (WHO, 2014). Hasil Riset Kesehatan Dasar tahun 2013 menunjukkan prevalensi gemuk pada remaja umur $16-18$ tahun sebanyak $7,3 \%$ yang terdiri dari $5,7 \%$ gemuk dan $1,6 \%$ obesitas. Prevalensi gemuk naik dari $1,4 \%$ (2007) menjadi 7,3\% (2013) (Depkes RI, 2013).

Kasus overweight pada remaja dikarenakan konsumsi makanan cepat saji (fast food), makanan yang tinggi natrium dan gula serta kurangnya pengetahuan mengenai pemilihan makanan sehat dan didukung kurangnya aktivitas fisik (Sri dan Sari, 2008). Berdasarkan Riskesdas 2013 prevalensi obesitas di Provinsi Yogyakarta pada kelompok umur 13 - 15 tahun sebesar 2,6\% dan DIY sendiri masuk dalam 15 provinsi dengan prevalensi sangat gemuk atau obesitas yang tinggi (Depkes RI, 2013). Remaja yang mengalami overweight memiliki resiko sebanyak $70 \%$ untuk mengalami overweight atau obesitas pada saat dewasa (Soegih dan Wiramihardja, 2009).

Kegemukan merupakan faktor risiko untuk terjadinya penyakit kardiovaskuler, hipertensi, diabetes mellitus, batu empedu dan berbagai penyakit degeneratif lainnya. Kegemukan juga merupakan salah satu faktor yang mempengaruhi terjadinya peningkatan kadar gula darah. Kadar gula darah yang meningkat ini dikarenakan sel - sel beta pulau Langerhans menjadi kurang peka terhadap rangsangan serta adanya penekanan jumlah reseptor insulin pada sel tubuh. Massa lemak tubuh pada penderita overweight dan obesitas yang menumpuk dapat menyebabkan peningkatan pelepasan asam lemak bebas (Free Fatty Acid/FFA) sehingga menghambat kerja insulin dan pada akhirnya terjadi kegagalan absorbsi glukosa ke dalam sel. Kegagalan absorbs glukosa ke dalam sel ini akan mengakibatkan peningkatan kadar glukosa darah (Guyton, 2007; Kaban, 2007).

Pencegahan dan penanggulangan masalah overweight dapat dilakukan dengan terapi gizi. Terapi gizi yang diberikan dapat berupa pemberian jenis makanan atau minuman rendah energi namun serat tinggi. Makanan tinggi serat memerlukan waktu yang lebih lama dalam proses pengunyahan sehingga meningkatkan jumlah air liur dan jumlah asam lambung yang dapat menyebabkan distensi lambung atau perut terasa penuh. Makanan yang mengandung serat larut air dapat membantu dalam respon insulin dan glukosa darah yang berujung pada penurunan rasa lapar setelah mengkonsumsinya (Velcu dan Cottam, 2008). Salah satu contoh jenis makanan yang mengandung tinggi serat dengan energi rendah adalah kacang tanah.

Kacang tanah (Arachis hypogaea L.) sebanyak 100 gram mengandung 25 gram protein, 43 gram lemak, dan 8,5 gram serat pangan, lemak tak jenuh $21 \%$, asam lemak jenuh $10 \%$, karbohidrat, vitamin $\mathrm{A}$, vitamin $\mathrm{B}$, Vitamin C, Vitamin D, Vitamin E, Vitamin K, fitosterol, magnesium, tembaga, fosfor, kalium, seng omega-3, omega-9, dan lesitin (Nuris, 2011). Kacang tanah juga merupakan salah satu bahan makanan yang memiliki indeks glikemik rendah, yang membuat peningkatan kadar glukosa darah dapat berlangsung lambat dan puncak kadar gulanya menjadi rendah (Widowati, dkk, 2008).

FAOSTAT mengatakan bahwa sebanyak 85\% kacang tanah yang tersedia di Indonesia dimanfaatkan sebagai bahan pangan dengan tingkat konsumsi rata-rata $2,4 \mathrm{~kg} / \mathrm{kapita} / \mathrm{tahun}$ dalam bentuk kacang rebus atau goreng, bumbu pecel atau gado-gado, kacang garing atau asin, biskuit, permen, bahan pengisi roti dan berbagai kue, minyak nabati, selai, tepung (FAOSTAT, 2009). Salah satu produk olahan kacang tanah yang mulai dicoba dikembangkan adalah susu kacang tanah.

Penelitian oleh Hanni dan Probosari (2014) pada wanita obesitas mengatakan bahwa terdapat penurunan kadar glukosa darah postprandial yang bermakna sebesar $13,6 \mathrm{mg} /$ dl setelah pemberian kacang tanah kukus sebanyak 28 gram selama 14 hari.

Susu kacang tanah yang diberikan pada penelitian ini berdasarkan kebutuhan serat sehari dan energi, dengan estimasi susu kacang tanah dapat memenuhi $10 \%$ dari kebutuhan energi dan serat total sehari. Formulasi susu kacang tanah yang diberikan sebanyak $180 \mathrm{ml}$. Formulasi ini berasal dari 30 gram kacang tanah, $220 \mathrm{ml}$ air dan gula jagung 2,5 gram. Pemilihan tempat penelitian berdasarkan penelitian Mustikaningsih D, dkk., (2015) yang menunjukkan bahwa SMA Negeri 9 Yogyakarta berada pada urutan keempat dan SMA Negeri 6 berada pada urutan 
ketiga yang memiliki kejadian obesitas terbanyak di antara SMA-SMA yang ada di Yogyakarta.

Penelitian ini bertujuan mengkaji efek pemberian susu kacang tanah terhadap perubahan berat badan dan kadar glukosa darah pada remaja putri overweight di Yogyakarta.

\section{METODE PENELITIAN}

Penelitian ini merupakan quasi eksperimental dengan desain one group pre-post test design. Variabel bebas pada penelitian ini adalah pemberian susu kacang tanah, variabel terikat adalah berat badan dan kadar glukosa darah dengan variabel luar berupa aktivitas fisik dan asupan makan. Penelitian ini dilaksanakan bulan September 2017-Mei 2018 dengan pemberian intervensi susu kacang tanah selama 14 hari sebanyak $180 \mathrm{ml}$ sebagai selingan pagi dengan suhu pemberian pada kisaran 4oC. Kadar glukosa darah diambil dari sampel darah sebanyak $3 \mathrm{ml}$ melalui darah vena pada pagi hari sebelum intervensi dan pada hari kelima belas. Berat badan diukur menggunakan timbangan injak dengan ketelitian 0,01 kg sebelum intervensi dan pada hari kelima belas sesudah penelitian. Aktivitas fisik dihitung menggunakan kuesioner aktivitas fisik empat kali selama empat hari intervensi. Asupan makan diukur menggunakan metode recall $1 \times 24$ jam sebanyak enam kali selama empat belas hari intervensi.

Penelitian ini dilaksanakan di Laboratorium Dietetika dan Kulinari Universitas Respati Yogyakarta dalam pembuatan produk susu kacang tanah, SMAN 6 dan SMAN 9 Yogyakarta sebagai tempat pengambilan data karakteristik, data berat badan, pengambilan darah dan sebagai tempat untuk intervensi pemberian susu kacang tanah, Laboratorium Parahita sebagai tempat pemeriksaan hasil glukosa darah.

Responden penelitian dipilih menggunakan purposive sampling dengan kriteria inklusi meliputi bersedia menjadi subjek penelitian dengan menandatangani informed consent, berjenis kelamin perempuan dengan kisaran usia 15-18 tahun serta memiliki IMT/U >+1 SD. Kriteria eksklusi penelitian meliputi riwayat penyakit DM, dislipidemia, PJK dan hipertensi serta memiliki alergi kacang dan olahannya. Teknik sampling yang digunakan pada penelitian ini adalah teknik sample random sampling dengan besar sampel sebanyak 14 subjek dan ditambah pertimbangan drop out sebanyak $10 \%$ sehingga besar sampel penelitian adalah 16 sampel.

Data primer meliputi identitas diri, berat badan, tinggi badan, kebiasaan makan menggunakan diukur menggunakan formulir semi quantitatif food frequency questionaire (SQFFQ), asupan makan dan kadar glukosa darah.

Data kebiasaan makan dan asupan makan tersebut kemudian dikonversi dari ukuran rumah tangga menjadi gram per hari, kemudian dianalisis menggunakan nutrisurvey. Data pengukuran berat badan, tinggi badan dan IMT/U diperoleh secara langsung melalui pengukuran antropometri. Analisis data menggunakan paired $t$ test dan regresi linear untuk mengetahui variabel mana yang mempengaruhi penurunan berat badan dan kadar glukosa darah. Penelitian telah mendapatkan persetujuan dari Komisi Etik Penelitian Universitas Respati Yogyakarta dengan nomor: 052.4/FIKES/PL///2018.

\section{HASIL DAN PEMBAHASAN}

\section{Gambaran Umum Penelitian}

Responden yang terlibat dalam penelitian ini sebanyak 16 orang dengan pemberian intervensi susu kacang tanah sebanyak $180 \mathrm{ml}$ satu kali selama 14 hari. Intervensi susu kacang tanah dilakukan sebagai pengganti selingan pagi. Kandungan serat kasar pada susu kacang tanah yang digunakan dalam penelitian ini berdasarkan hasil laboratorium sebesar 6,70 gram. Responden akan melakukan puasa selama 10 jam sebelum dan sesudah intervensi untuk diukur kadar glukosa darah. Pembuatan susu kacang tanah dilakukan satu kali setiap dua hari.

\section{Karakteristik Subjek}

Karakteristik subyek dalam penelitian ini dapat dilihat pada tabel 1 . 
Tabel 1. Karakteristik subjek

\begin{tabular}{|c|c|c|c|c|c|}
\hline Variabel & $\mathrm{N}$ & $M$ in & Maks & $\bar{X} \pm \mathrm{SD}$ & $p$ \\
\hline \multicolumn{6}{|l|}{ Karakteris tik } \\
\hline Usia (tahun) & 16 & 15 & 17 & $15,88 \pm 0,72$ & 0,004 \\
\hline $\mathrm{BB}(\mathrm{kg})$ & 16 & 55 & 68 & $61,03 \pm 3,43$ & $0,886^{*}$ \\
\hline TB (cm) & 16 & 146 & 165 & $156,56 \pm 3,10$ & $0,981^{*}$ \\
\hline $\mathrm{IMT} / \mathrm{U}$ & 16 & 1,11 & 1,54 & $1,29 \pm 0,13$ & $0,994^{*}$ \\
\hline \multicolumn{6}{|l|}{$\begin{array}{l}\text { Kebiasaan } \\
\text { Makan }\end{array}$} \\
\hline Energi (kkal) & 16 & 1157 & 2952 & $1943,72 \pm 505,77$ & $0,151^{*}$ \\
\hline Protein (g) & 16 & 42,70 & 115 & $65,59 \pm 20,81$ & $0,061^{*}$ \\
\hline Lemak (g) & 16 & 22,60 & 67,90 & $44,07 \pm 11,12$ & $0,823^{*}$ \\
\hline Karbohidrat (g) & 16 & 173 & 545,50 & $317,16 \pm 98,12$ & 0,033 \\
\hline Serat (g) & 16 & 5,90 & 36 & $13,98 \pm 8,74$ & 0,006 \\
\hline
\end{tabular}

Tabel 1 menunjukkan bahwa menggunakan SQFFQ menunjukkan subyek memiliki homogenitas berdasarkan bahwa kebiasaan makan subyek sebelum berat badan, tinggi badan dan IMT/U. penelitian memiliki homogenitas berdasarkan Kebiasaan makan responden yang diukur asupan energi, protein dan lemak $(p>0,05)$.

Tabel 2. Perbedaan berat badan dan kadar glukosa sebelum dan sesudah intervensi

\begin{tabular}{lllll}
\hline Variabel & pre & post & $\Delta$ & $P$ \\
\hline BB $(\mathrm{kg})$ & $61,03 \pm 3,44$ & $60,34 \pm 3,25$ & $-0,69$ & $0,016^{*}$ \\
\hline Kadar glukosa darah & $73,44 \pm 9,21$ & $72,50 \pm 5,56$ & $-0,94$ & 0,654 \\
\hline \multicolumn{2}{l}{; selisih berat badan atau kadar glukosa darah sesudah dan sebelum intervensi } \\
$p^{*}$ significant, paired t test $(p<0,05)$
\end{tabular}

Tabel 2 menunjukkan bahwa variabel berat badan dan kadar glukosa darah sebelum dan sesudah intervensi menunjukkan adanya penurunan masing- masing sebesar $0,69 \mathrm{~kg}$ dan $0,94 \mathrm{mg} / \mathrm{dl}$. Hasil analisis lanjut untuk berat badan dan kadar glukosa darah menggunakan paired $t$ test menunjukkan bahwa ada perbedaan berat badan sebelum dan sesudah intervensi susu kacang tanahselama empatbelas haritetapi untuk kadar glukosa darah menunjukkan bahwa tidak terdapat perbedaan kadar glukosa darah sebelum dan sesudah intervensi susu kacang tanah.

\section{Pengaruh Pemberian Susu Kacang Tanah Terhadap Berat Badan}

Hasil uji statistik menunjukkan perbedaan yang signifikan $(p=0,016)$ sebelum dan sesudah pemberian susu kacang tanah terhadap kadar berat badan pada remaja perempuan overweight yang berusia 15-17 tahun. Penurunan berat badan pada penelitian ini sebesar $0,69 \mathrm{~kg}$ (Tabel 2).

Hasil penelitian ini sejalan dengan penelitian yang dilakukan oleh Serquiz, dkk, (2016). Penelitian Serquiz, dkk, (2016) menyatakanbahwaterdapatpengaruh pemberian permen kacang tanah sebanyak $22 \mathrm{mg} / \mathrm{gramBB} /$ hari selama 14 hari terhadap perubahan berat badan $(p<0,05)$ pada hewan coba. Penurunan berat badan pada penelitian ini dimungkinkan karena kandungan serat yang terdapat pada susu kacang tanah. Kandungan serat dalam susu kacang tanah dapat membantu dalam mengontrol berat badan. Mekanisme serat larut air adalah mengikat cairan serta beberapa hemiselulosa mempunyai kemampuan menahan air dan dapat membentuk cairan kental dalam usus halus. Serat larut air pada akhirnya dapat menunda pengosongan makanan dari lambung, menghambat percampuran isi saluran cerna dengan enzim-enzim pencernaan sehingga terjadi pengurangan penyerapan zat-zat makanan di bagian proksimal. Makanan akan tinggal dalam saluran pencernaan dalam waktu yang relatif singkat sehingga absorbsi zat makanan akan berkurang. Selain itu makanan yang mengandung serat 
relatif tinggi akan memberi rasa kenyang sehingga menurunkan konsumsi makanan. Makanan dengan kandungan serat kasar yang tinggi biasanya mengandung kalori rendah, kadar gula dan lemak rendah yang dapat membantu mengurangi terjadinya obesitas (Albiner, 2003).

Penurunan berat badan dapat disebabkan oleh kandungan protease inhibitor pada kacang tanah yang merupakan senyawa yang bersifat hipoglisemik melalui mekanisme pembentukan kompleks TI-tripsin dalam pencernaan. Pembentukan komplek tersebut memacu peningkatan sekresi hormone cholecystokinin (CCK), dengan demikian meningkatnya hormon CCK efeknya dapat mengontrol rasa kenyang (Nuris D, 2011).

\section{Pengaruh pemberian susu kacang tanah terhadap kadar glukosa darah}

Hasil uji statistik menunjukkan tidak terdapat perbedaan yang signifikan sebelum dan sesudah pemberian susu kacang tanah terhadap kadar glukosa darah pada remaja perempuan overweight yang berusia 15-17 tahun $(p=0,654)$ meskipun terjadi penurunan kadar glukosa darah sebesar 0,94 mg/dl (Tabel 2).

Hasil penelitian ini tidak sejalan dengan penelitian yang dilakukan oleh Tri dan Enny (2014). Penelitian Tri dan Enny (2014) menyatakan bahwa terdapat pengaruh pemberian kacang tanah kukus sebanyak 28 gram selama 14 hari terhadap kadar glukosa darah. Hal ini dibuktikan dengan hasil analisis statistik $p=0,02(p<0,05)$ dan terjadi penurunan kadar glukosa darah sebesar $13,6 \mathrm{mg} / \mathrm{dL}$ pada perempuan overweight dan obesitas. Kandungan serat pada susu kacang tanah dapat membantu menurunkan kadar glukosa darah. Pemberian serat pangan dalam jangka waktu lama mampu menurunkan tingkat glikemik serum, yaitu dengan memperlambat penyerapan glukosa melalui efek pengosongan lambung dan viskositas feses serta menurunkan respons insulin. Serat pangan juga menghambat difusi glukosa serta akan menunda penyerapan dan pencernaan karbohidrat. Efek ini memiliki dampak positif dalam keberadaan serat pangan untuk mengurangi laju penyerapan glukosa, sehingga tubuh tidak akan mengalami kelebihan glukosa. Diet yang mengandung banyak serat menyebabkan penundaan absorbsi bahan makanan di usus termasuk penundaan absorbsi karbohidrat sehingga kadar glukosa darah menurun.
Mekanisme serat pada metabolisme gula darah berkaitan dengan fungsi dan karakteristik serat. Serat di dalam tubuh dapat menyerap cairan dan kemudian membentuk gel di dalam lambung. Gel inilah yang dapat memperlambat proses pengosongan lambung dan penyerapan zat gizi. Gel juga dapat memperlambat gerak peristaltik zat gizi dari dinding usus halus menuju daerah penyerapan sehingga terjadi penurunan kadar gula darah (Witasari, 2009). Kadar glukosa darah sebanding dengan jumlah insulin yang dibutuhkan sehingga jika peningkatan kadar glukosa darah dapat ditekan maka produksi insulin akan menurun.

Serat yang tinggi juga dapat memperbaiki kadar gula darah yaitu berhubungan dengan kecepatan penyerapan makanan (karbohidrat) masuk ke dalam aliran darah yang dikenal dengan glycaemic index (GI). GI ini mempunyai angka dari 0 sampai 100 dimana makanan yang cepat dirombak dan cepat diserap masuk ke aliran darah mempunyai angka Gl yang tinggi sehingga dapat meningkatkan kadar gula darah. Sebaliknya makanan yang lambat dirombak dan lambat diserap masuk ke aliran darah mempunyai angka $\mathrm{Gl}$ yang rendah sehingga dapat menurunkan kadar gula darah. Disamping memberikan manfaat terhadap kesehatan, serat makanan juga telah lama diketahui sebagai penyebab ketidaktersediaan (non-availability) beberapa mineral.

Serat merupakan komponen yang tidak dapat dicerna dan diserap di dalam usus halus. Bagian serat yang tidak tercerna akan menuju ke dalam usus besar. Serat akan diubah menjadi substrat yang dapat difermentasikan oleh bakteri di dalam usus besar. Fermentasi serat oleh bakteri menghasilkan asam-asam lemak rantai pendek jenis asetat dan propionat. Asam lemak rantai pendek dapat meningkatkan aktifitas dari bifidobakteria dan laktobacili di dalam usus yang dapat meningkatkan kesehatan tubuh dan berpengaruh pada metabolisme insulin di dalam tubuh sehingga efek hipoglikemik dapat terjadi (Rimbawan, 2004).

Asam asetat diserap ke dalam vena porta sehingga masuk ke hati dan pembuluh darah. Asam asetat digunakan sebagai sumber energi untuk jaringan besar non hepar. Asetat dapat menurunkan asam-asam lemak bebas di aliran darah dalam jangka waktu yang lama. Hal ini mempunyai efek baik bagi penurunan kadar gula darah dan sensitivitas insulin dalam jangka waktu lama karena asamasam lemak bebas dapat menghambat proses 
utilasi gula darah di jaringan dan membantu menghambat resistensi insulin (Witasari, 2009).

Asam propionat merupakan senyawa utama asam lemak rantai pendek yang dapat berperan dalam metabolisme glukosa. Asam propionat juga menurunkan reduksi asamasam lemak bebas di dalam darah yang dapat menghambat resistensi insulin dan mencegah proses utilasi gula darah oleh jaringan dalam jangka waktu lama. Kerja propionat tersebut dapat menyebabkan peningkatan sekresi insulin sehingga terjadi penurunan kadar gula darah (Witasari, 2009).

Kacang tanah juga kaya akan magnesium yang membantu meningkatkan sensitivitas insulin (Garry, 1999). Magnesium merupakan kofaktor beberapa enzim pada metabolisme karbohidrat seperti berperan pada aktivasi ATPMg kompleks yang dibutuhkan oleh semua enzim pada glikolisis, termasuk pada reaksi fosforilasi. Penelitian in vitro dan in vivo menunjukkan bahwa insulin dapat mengatur perpindahan magnesium dari ekstraseluler ke intraseluler. Konsentrasi magnesium intraselular juga terbukti efektif dalam aksi modulasi insulin, terutama pada metabolisme oksidatif glukosa. Konsentrasi magnesium bebas intraseluler sangat penting dalam fosforilasi tirosin-kinase pada reseptor insulin, seperti protein kinase lainnya, dan semua ATP dan fosfat mentransfer enzim yang terkait, seperti CaATPase (enzim ATP kalsium) pada membran plasma dan retikulum endoplasma. Konsentrasi magnesium yang rendah pada intraselular, seperti yang ditemukan pada pasien DMT2 dan hipertensi, dapat mengakibatkan tidak sempurnanya aktivitas fosforilasi tirosin kinase pada tingkat reseptor insulin yang mengakibatkan konsentrasi kalsium (Ca) intraseluler yang berlebihan. Keseimbangan magnesium dan kalsium berperan dalam penurunan aksi insulin dan memperburuk resistensi insulin pada pasien diabetes. Sehingga, ketidakseimbangan magnesium dan kalsium akan memperburuk terjadinya resistensi insulin (Nishijawa, 2007). Hasil uji multivariat menggunakan regresi linearuntukmelihatpengaruhvariabelluardengan variabel terikat dapat dilihat pada tabel 3. Variabel berat badan tidak dianalisis karena asupan makan dan aktivitas fisik memiliki nilai $p>0,05$. Penelitian ini akan menganalisis perubahan kadar glukosa darah dengan asupan energi dan asupan karbohidrat karena memiliki nilai $p<0,25$.

\begin{tabular}{|c|c|c|c|c|c|}
\hline \multicolumn{6}{|c|}{$\begin{array}{l}\text { Tabel 3. Analisis multivariat variabel luar terhadap perubahan } \\
\text { kadar glukosa }\end{array}$} \\
\hline Model & Variabel & $\beta$ & $P$ value * & $R^{2}$ & $P$ value \\
\hline \multirow{3}{*}{1} & Konstanta & 20,010 & 0,188 & \multirow{3}{*}{0,268} & \multirow{3}{*}{0,132} \\
\hline & Energi & 0.005 & 0,731 & & \\
\hline & Karbohid rat & $-0,121$ & 0,157 & & \\
\hline \multirow{2}{*}{2} & Konstanta & 23,130 & 0,054 & \multirow{2}{*}{0,261} & \multirow{2}{*}{0,043} \\
\hline & Karbohid rat & $-0,098$ & 0,043 & & \\
\hline
\end{tabular}

Tabel 3 menunjukkan bahwa asupan karbohidrat memiliki pengaruh terhadap perubahan kadar glukosa darah dibandingkan asupan energi. Persamaan regresi yang dapat dihasilkan berdasarkan tabel 3 adalah $\mathrm{y}=23,130-0,098(\mathrm{x})$, dimana y adalah perubahan kadar glukosa darah dan $\mathrm{x}$ adalah asupan karbohidrat. Tabel 3 juga menunjukkan bahwa sebanyak 26,1\% perubahan kadar glukosa dipengaruhi oleh asupan karbohidrat dan sisanya dipengaruhi oleh variabel lain.

\section{PENUTUP}

Pemberiansusukacangtanahmemiliki pengaruh signifikan terhadap berat badan tetapi tidak demikian dengan kadar glukosa remaja putri overweight meskipun pemberian susu kacang tanah dapat menurunkan berat badan dan kadar glukosa darah. Keterbatasan pada penelitian ini adalah tidak memasukkan kadar glukosa darah tinggi sebagai kriteria inklusi sehingga rata- rata responden penelitian memiliki kadar glukosa darah normal serta tidak menanyakan kepada subyek 
mengenai konseling pengaturan makan yang berkaitan dengan berat badan.

\section{DAFTAR PUSTAKA}

Albiner. 2003. Pendekatan Fortifikasi Pangan untuk Mengatasi Masalah Kekurangan Gizi Makro. http://repository.usu.ac.id. Badan Penelitian dan Pengembangan Kesehatan. 2013. Laporan Hasil Riset Kesehatan Dasar (Riskesdas) Indonesia tahun 2013. Jakarta: Departemen Kesehatan Republik Indonesia. FAOSTAT. 2009. Statistical data of food balance sheet. www.fao.org.

Garry E, Fraser. 1999. Nut Comsumption, Lipids, and Risk of a Coronary Event. Clin.Cardiol.22;(Suppl. III), III-11-III-15. Guyton, A.C., dan Hall, J.E., 2007. Buku Ajar Fisiologi Kedokteran Edisi 11. Jakarta: EGC, 917-918. Kaban, S. 2007. Diabetes Mellitus Tipe 2 Di Kota Sibolga Tahun 2005. Majalah Kedokteran Nusantara. 4(2). Mustikaningsih D, Hartini TNS, Huda N. 2015. Persepsi tentang Fast Food dan Frekuensi Konsumsi Fast Food sebagai Faktor Risiko Terjadinya Obesitas pada Remaja di Kota Yogyakarta. Yogyakata : Jurnal Nutrisia, 17(2): 58-64. Nishizawa Y, Morii H, Durlach J. 2007. New Perspective in Mg Research Nutrition and Health. 213-223: http://www. springer.com/978-1-84628-388-8.

Nuris D. 2011. Aneka Manfaat Kulit Buah dan Sayuran. Yogyakarta: Penerbit Andi Purnawati, I. 2009. Prevalensi Obesitas di Indonesia. Jakarta: Universitas Indonesia.

Putri THD dan Enny P. 2014. Pengaruh Pemberian Kacang Tanah Kukus (Arachis hypogeae L) Terhadap Kadar Glukosa Darah Posprandial pada Perempuan Overweght dan Obesitas. Semarang: Journal of Nutrition College; 3(1). Rimbawan, Siagian A. 2004. Indeks Glikemik Pangan, Cara Mudah Memilih Pangan yang Menyehatkan.
Jakarta: Penebar Swadaya. Sari DA. 2014. Hubungan Pengetahuan Gizi, Kebiasaan Konsumsi Fast Food dan Aktifitas Fisikn dengan Kejadian Overweight pada Siswa SMP AL Islam 1 Surakarta. Skripsi Program Studi Ilmu Gizi S1. Universitas Muhamadiyah Surakarta. Serquiz AC, Satiro DSP, Lima VCO, Rocha LRM, Oliveria CN, Sampaio TBM, Carneiro MAA, Machado RJA, Santos EA, Uchoa AF, Morais AHA. 2016. The Effect of a High Calorie Diet Containing a Peanut Candy on Weight Loss. Internasional Food Reseach Journal 23(1): 248-156

Soegih RR, Wiramihardja KK. 2009. Obesitas Permasalahan dan Terapi Praktis. Jakarta: Sagung Seto Velcu L, dan Cottam DR. 2008. Fiber and Obesity. Dalam K. Keller (Ed). Encyclopedia of Obesity. UK : Sage Publication Inc. Widowati SBAS, Santosa dan Astawan. 2008. Karakterisasi Mutu dan Pengaruh Proses Pratanak terhadap Indeks Glikemik Berbagai Varietas Beras Indonesia untuk Meningkatkan Kesehatan Masyarakat dan Ketahanan Pangan. Laporan Hasil Penelitian Riset Insentif. BB Litbang Pascapanen. Witasari, dkk. 2009. Hubungan Tingkat Pengetahuan, Asupan Karbohidrat dan Serat dengan Pengendalian Kadar Glukosa Darah pada Penderita Diabetes Melitus Tipe 2. Jurnal Penelitian Sains dan Teknologi;10(2).

World Health Organization (WHO). 2014. Prevalence Obesity and Overweight. Diakses pada 20 November 2017. Dari http://www.who.Int/ growthref /who.bmi.for.age/enhtml. 